EVALUATING THE EFFECTS OF FLY ASH EXPOSURE ON FISH EARLY LIFE STAGES: FATHEAD MINNOW EMBRYO-LARVAL TESTS

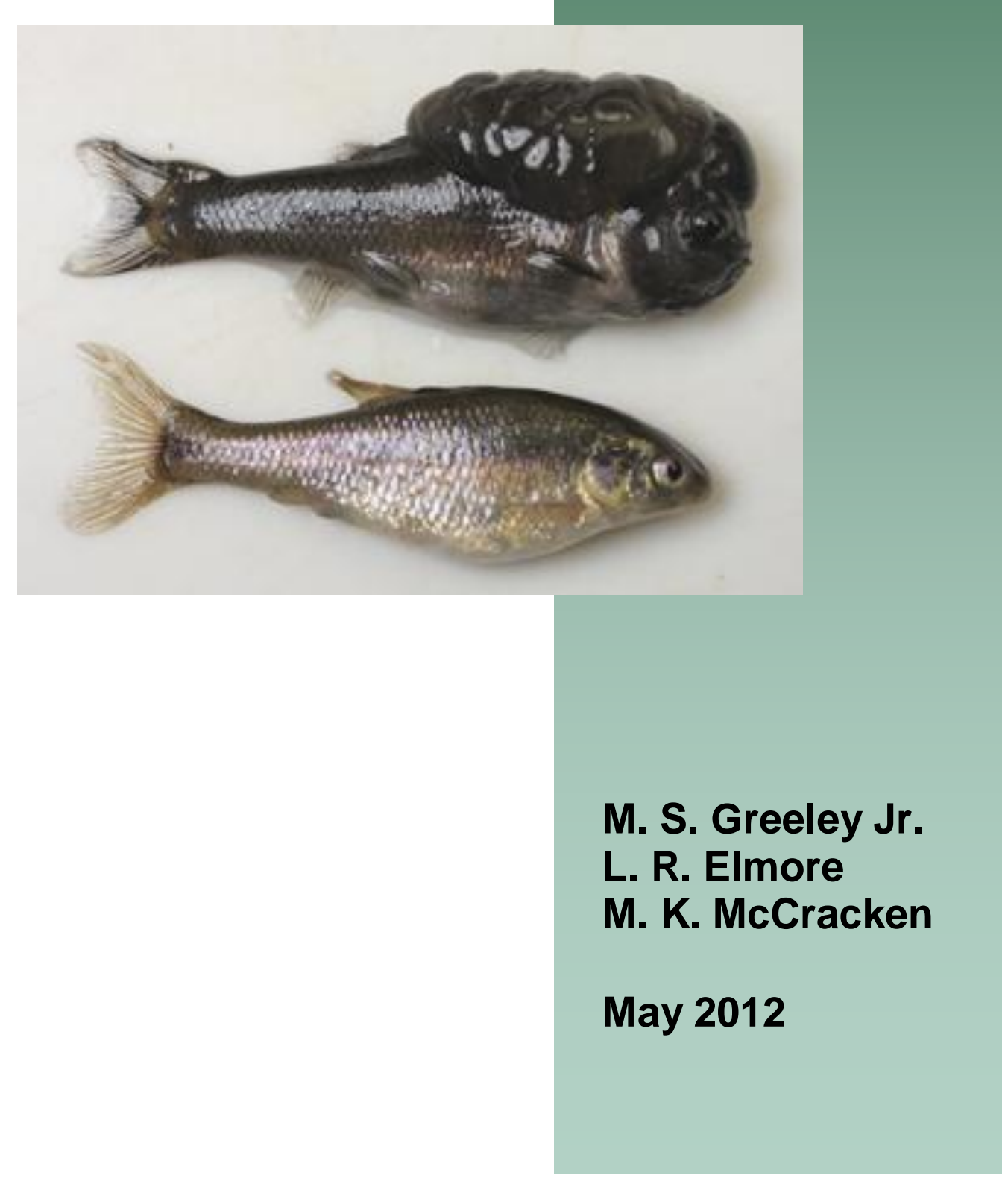




\section{DOCUMENT AVAILABILITY}

Reports produced after January 1, 1996, are generally available free via the U.S. Department of Energy (DOE) Information Bridge.

Web site http://www.osti.gov/bridge

Reports produced before January 1, 1996, may be purchased by members of the public from the following source.

National Technical Information Service

5285 Port Royal Road

Springfield, VA 22161

Telephone 703-605-6000 (1-800-553-6847)

TDD 703-487-4639

Fax 703-605-6900

E-mail info@ntis.fedworld.gov

Web site http://www.ntis.gov/support/ordernowabout.htm

Reports are available to DOE employees, DOE contractors, Energy Technology Data Exchange (ETDE) representatives, and International Nuclear Information System (INIS) representatives from the following source.

Office of Scientific and Technical Information

P.O. Box 62

Oak Ridge, TN 37831

Telephone 865-576-8401

Fax 865-576-5728

E-mail reports@adonis.osti.gov

Web site http://www.osti.gov/contact.html

This report was prepared as an account of work sponsored by an agency of the United States Government. Neither the United States Government nor any agency thereof, nor any of their employees, makes any warranty, express or implied, or assumes any legal liability or responsibility for the accuracy, completeness, or usefulness of any information, apparatus, product, or process disclosed, or represents that its use would not infringe privately owned rights. Reference herein to any specific commercial product, process, or service by trade name, trademark, manufacturer, or otherwise, does not necessarily constitute or imply its endorsement, recommendation, or favoring by the United States Government or any agency thereof. The views and opinions of authors expressed herein do not necessarily state or reflect those of the United States Government or any agency thereof. 


\title{
EVALUATING THE EFFECTS OF FLY ASH EXPOSURE ON FISH EARLY LIFE STAGES: FATHEAD MINNOW EMBRYO-LARVAL TESTS
}

\author{
M. S. Greeley, Jr. \\ L. R. Elmore \\ M. K. McCracken \\ May 2012

\begin{abstract}
Prepared for:
Tennessee Valley Authority

400 West Summit Hill Drive

Knoxville, Tennessee 37902-1499
\end{abstract} \\ Prepared by: \\ Environmental Sciences Division \\ Oak Ridge National Laboratory \\ Oak Ridge, Tennessee 37831 \\ managed by \\ UT Battelle, LLC \\ for the \\ U.S. Department of Energy \\ under Contract DE-AC05-00OR22725
}


[THIS PAGE LEFT BLANK INTENTIONALLY] 


\section{CONTENTS}

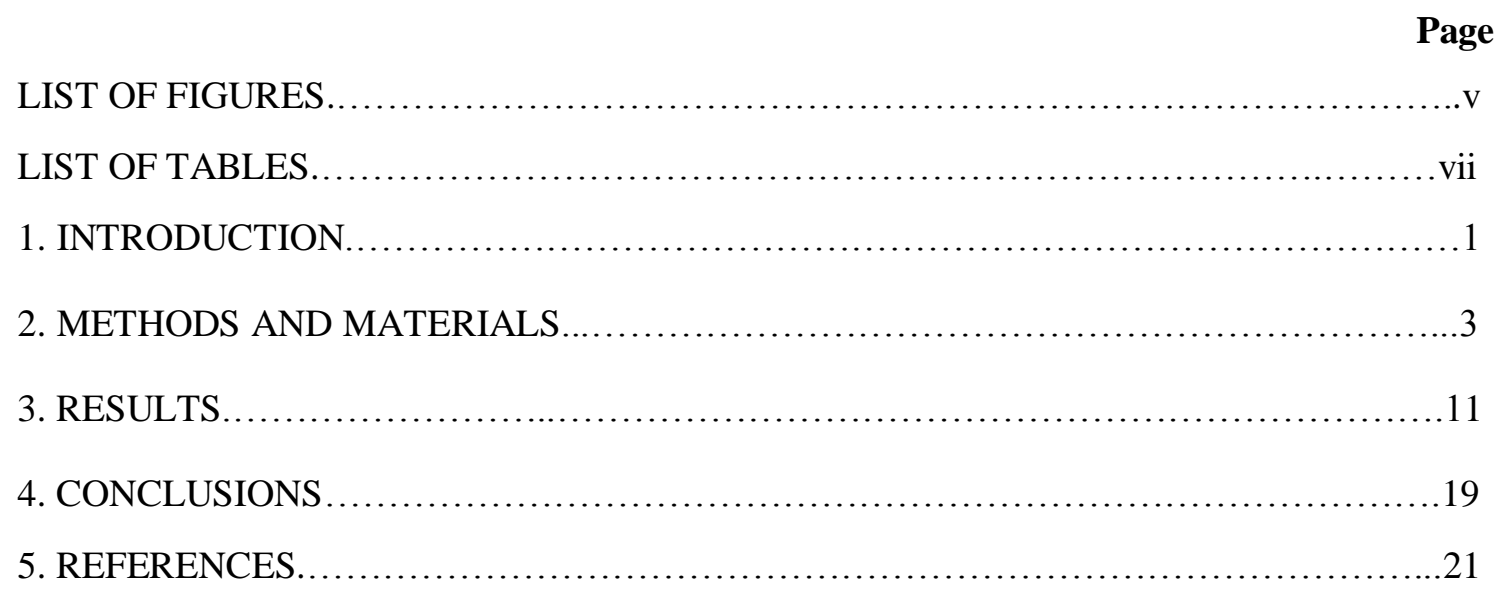


[THIS PAGE LEFT BLANK INTENTIONALLY] 


\section{LIST OF FIGURES}

Page

Fig. 1. Map showing sampling locations in the Emory River for sediment used in fathead minnow embryo-larval toxicity tests conducted by ORNL ...............

Fig. 2. Sediment sample from the lower Emory River being mixed at ORNL with a customized stainless steel bit attached to a variable-speed drill

Fig. 3. Fathead minnow embryo-larval test design of Emory River sediment samples:

A) random distribution of test containers with sediment and/or control water;

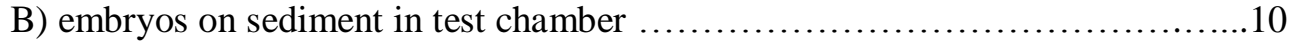

Fig. 4. Comparison of fathead minnow embryo-larval survival in Emory River water from ERM 8 upstream of the fly ash spill (controls) with survival on full-strength sediment samples containing fly ash from the lower Emory River (100\%) or reference sediment without fly ash from the upper

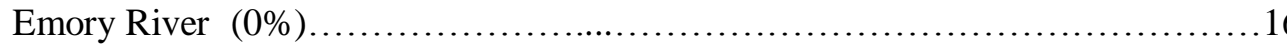


[THIS PAGE LEFT BLANK INTENTIONALLY] 


\section{LIST OF TABLES}

\section{Page}

Table 1. Relationship between ORNL and TVA sample identifiers for Emory River sediment tested for toxicity to fathead minnow embryos and larvae..............3

Table 2. Percent ash in sediment samples from the Emory River tested for toxicity to fathead minnow embryos and larvae........................................

Table 3. Selected chemical analyses ( $\mathrm{mg} / \mathrm{kg}$ dry wt) conducted on sediment samples from the Emory River tested for toxicity to fathead minnow embryos and larvae......6 6

Table 4. Summary Data from Fathead Minnow Embryo-Larval Toxicity Test of Emory River Sediment Sample A......................................... 12

Table 5. Summary Data from Fathead Minnow Embryo-Larval Toxicity Test of Emory River Sediment Sample B.............................................13

Table 6. Summary Data from Fathead Minnow Embryo-Larval Toxicity Test of Emory River Sediment Sample C...........................................14

Table 7. Summary Data from Fathead Minnow Embryo-Larval Toxicity Test of Emory River Sediment Sample D ........................................... 15

Table 8. Summary (mean \pm sd) of control water chemistry analyses conducted during fathead minnow embryo-larval toxicity testing of Emory River sediment samples...............................................................17

Table 9. Summary (mean \pm sd) of water chemistry analyses conducted on "discard" water removed from test chambers during daily water changes of fathead minnow embryo-larval toxicity test chambers 
[THIS PAGE LEFT BLANK INTENTIONALLY] 


\section{INTRODUCTION}

On December 22, 2008, a dike containing fly ash and bottom ash in an 84-acre complex of the Tennessee Valley Authority's (TVA) Kingston Steam Plant in East Tennessee failed and released a large quantity of ash into the adjacent Emory River. Ash deposits extended as far as 4 miles upstream (Emory River mile 6) of the Plant, and some ash was carried as far downstream as Tennessee River mile 564 ( 4 miles downstream of the Tennessee River confluence with the Clinch River). A byproduct of coal burning power plants, fly ash contains a variety of metals and other elements which, at sufficient concentrations and in specific forms, can be toxic to biological systems.

The effects of fly ash contamination on exposed fish populations depend on the magnitude and duration of exposure, with the most significant risk considered to be the effects of specific ash constituents, especially selenium, on fish early life stages. Uptake by adult female fish of fly ash constituents through the food chain and subsequent maternal transfer of contaminants to the developing eggs is thought to be the primary route of selenium exposure to larval fish (Woock and others 1987, Coyle and others 1993, Lemly 1999, Moscatello and others 2006), but direct contact of the fertilized eggs and developing embryos to ash constituents in river water and sediments is also a potential risk factor (Woock and others 1987, Coyle and others 1993, Jezierska and others 2009).

To address the risk of fly ash from the Kingston spill to the reproductive health of downstream fish populations, ORNL has undertaken a series of studies in collaboration with TVA including: (1) a field study of the bioaccumulation of fly ash constituents in fish ovaries and the reproductive condition of sentinel fish species in reaches of the Emory and Clinch Rivers affected by the fly ash spill; (2) laboratory tests of the potential toxicity of fly ash from the spill area on fish embryonic and larval development (reported in the current technical manuscript); (3) additional laboratory experimentation focused on the potential effects of long-term exposures to fly ash on fish survival and reproductive competence; and (4) a combined field and laboratory study examining the in vitro developmental success of embryos and larvae obtained from fish exposed in vivo for over two years to fly ash in the Emory and Clinch Rivers.

These fish reproduction and early life-stage studies are being conducted in conjunction with a broader biological monitoring program administered by TVA that includes a field study of the condition of larval fish in the Emory and Clinch Rivers along with assessments of water quality, sediment composition, ecotoxicological studies, terrestrial wildlife studies, and human and ecological risk assessment. Information and data generated from these studies will provide direct input into risk assessment efforts and will also complement and help support other phases of the overall biomonitoring program.

Fish eggs, in general, are known to be capable of concentrating heavy metals and other environmental contaminants from water-borne exposures during embryonic development (Jezierska and others 2009), and fathead minnow embryos in particular have been shown to concentrate methylmercury (Devlin 2006) as well as other chemical toxicants. This technical report focuses on the responses of fathead minnow embryos to simple contact exposures to fly ash in laboratory toxicity tests adapted from a standard fathead minnow (Pimephales promelas) 7-d embryo-larval survival and teratogenicity test (method 1001.0 in EPA 2002) with mortality, hatching success, and the incidences of developmental abnormalities as measured endpoints. 
[THIS PAGE LEFT BLANK INTENTIONALLY] 


\section{METHODS AND MATERIALS}

\section{Sediment Samples}

Bulk sediment samples containing ash from the Kingston fly ash spill were collected for TVA contractors by decontaminated box core and/or dedicated Vibecore from four locations in the lower Emory River within the spill zone (Fig. 1 and Table 1). Reference sediment was collected from a location in the Emory River upstream of the spill's influence. Percentages of ash in the lower Emory River samples varied from $46 \%-79 \%$ (Table 2), and samples were elevated in mercury, selenium, and arsenic as compared with reference sediment (Table 3 ).

Samples were transported to the Environmental Toxicology Laboratory at ORNL in 5 gallon buckets by refrigerated truck $\left(<6^{\circ} \mathrm{C}\right)$ and then stored at $\leq 4^{\circ} \mathrm{C}$ for $<60$ days before use. Prior to testing, sediment samples were mixed with a stainless steel drill attachment to reincorporate pore-water (Fig. 2), and samples A-D were remixed with reference sediment to obtain a concentration series for embryo-larval toxicity testing [100\% (full-strength A, B, C, or D sediment samples), 75\%, 50\%, 25\%, and 0\% (fullstrength reference sediment].

Table 1. Relationship between ORNL and TVA sample identifiers for Emory River sediment tested for toxicity to fathead minnow embryos and larvae.

\begin{tabular}{ccc}
\hline $\begin{array}{c}\text { ORNL } \\
\text { Sample ID }\end{array}$ & TVA Field Sample ID & Additional TVA ID \\
(see Fig. 1)
\end{tabular}




\section{ORNL-BULK ASH}

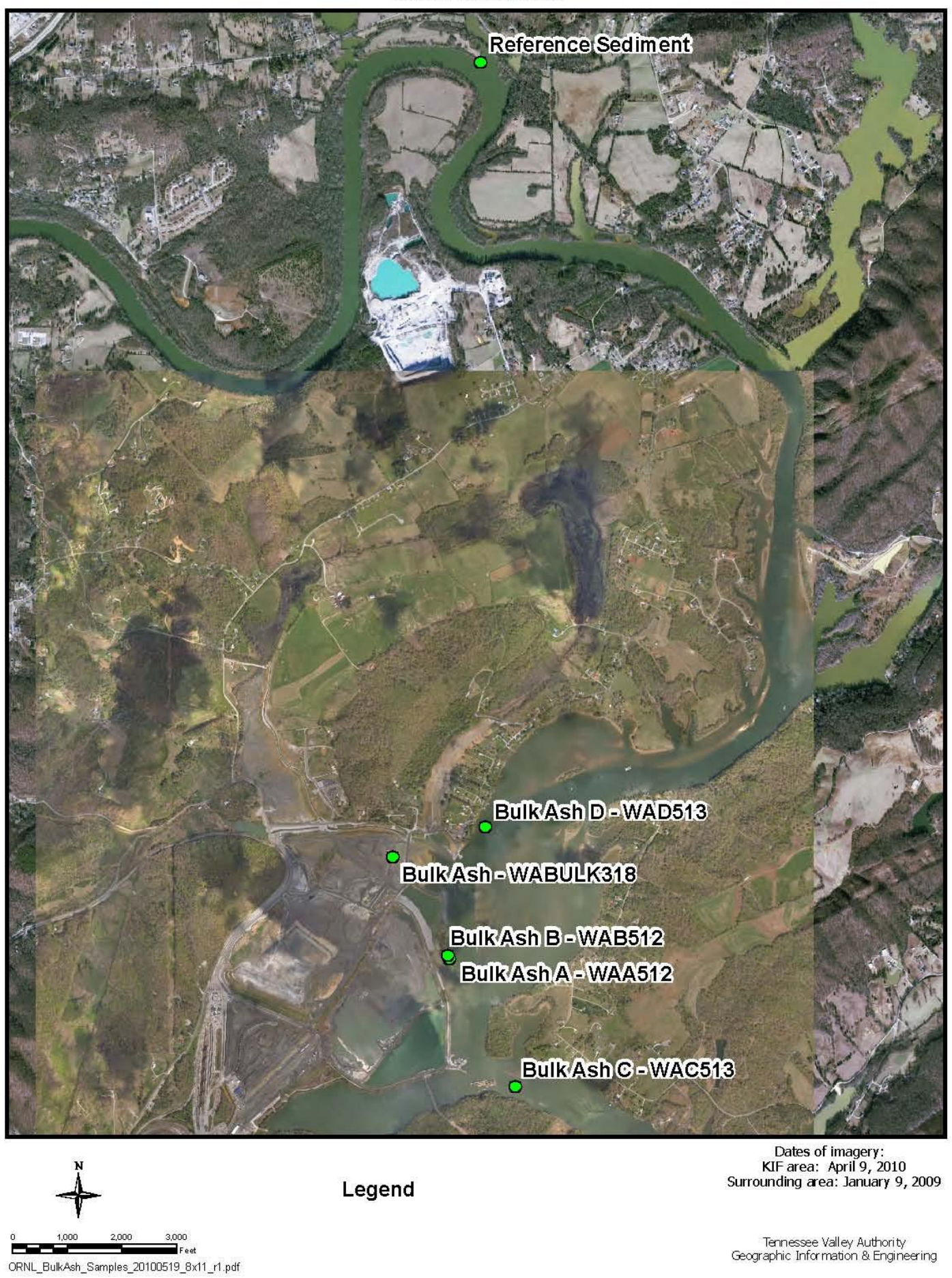

Figure 1. Map showing sampling locations in the Emory River for sediment used in fathead minnow embryo-larval toxicity tests conducted by ORNL. Map supplied by TVA. Includes an extra sampling location (WABULK318) for ash used in a separate study (results not presented in current report). 
Table 2. Percent $\operatorname{ash}^{a}$ in sediment samples from the Emory River tested for toxicity to fathead minnow embryos and larvae.

\begin{tabular}{ccl}
\hline Sample & $\%$ Ash in Sample & Additional Description \\
\hline A & 67 & None \\
B & 75 & Diatoms and organic particulates noted \\
C & 78 & Organic particulates noted \\
D & 46 & Diatoms and organic particulates noted \\
\hline
\end{tabular}

${ }^{a}$ Characterization supplied to ORNL by TVA; analysis by RJ Lee. 
Table 3. Selected chemical analyses ( $\mathrm{mg} / \mathrm{kg}$ dry except mercury; mercury species in $\mu \mathrm{g} / \mathrm{kg}$ dry $w \mathrm{t}$ ) conducted on sediment samples from the Emory River tested for toxicity to fathead minnow embryos and larvae. Shaded text indicates non-detects at analytical reporting limits. Analytical results supplied to ORNL by TVA; analyses by TestAmerica and Frontier Geosciences Inc (metal speciation). Data unavailable for sample C.

Sediment Sample

\begin{tabular}{lcccc} 
Chemical name & $\mathrm{A}$ & $\mathrm{B}$ & $\mathrm{D}$ & Reference \\
\hline Total arsenic & 59.4 & 84.0 & 45.8 & 2.5 \\
Arsenate & 52.0 & 70.0 & 32.1 & 1.7 \\
Arsenite & 7.1 & 2.9 & 22.5 & $\mathbf{0 . 2}$ \\
Inorganic arsenic & 59 & 73 & 55 & 2 \\
Total mercury & 82 & 145 & 109 & 28 \\
Methyl mercury & 0.02 & $\mathbf{0 . 0 1}$ & $\mathbf{0 . 0 1}$ & 0.32 \\
Inorganic mercury & 81 & 145 & 109 & 28 \\
Total selenium & 3.76 & 9.95 & 3.61 & $\mathbf{0 . 7 0}$ \\
Selenite & 2.88 & 6.30 & 1.71 & $\mathbf{0 . 9 9}$ \\
Selenate & $\mathbf{0 . 6 9}$ & $\mathbf{0 . 6 4}$ & $\mathbf{0 . 7 9}$ & $\mathbf{0 . 7 8}$ \\
Organic selenium & 0.88 & 3.60 & 1.90 & $\mathbf{0 . 9 9}$ \\
\hline
\end{tabular}




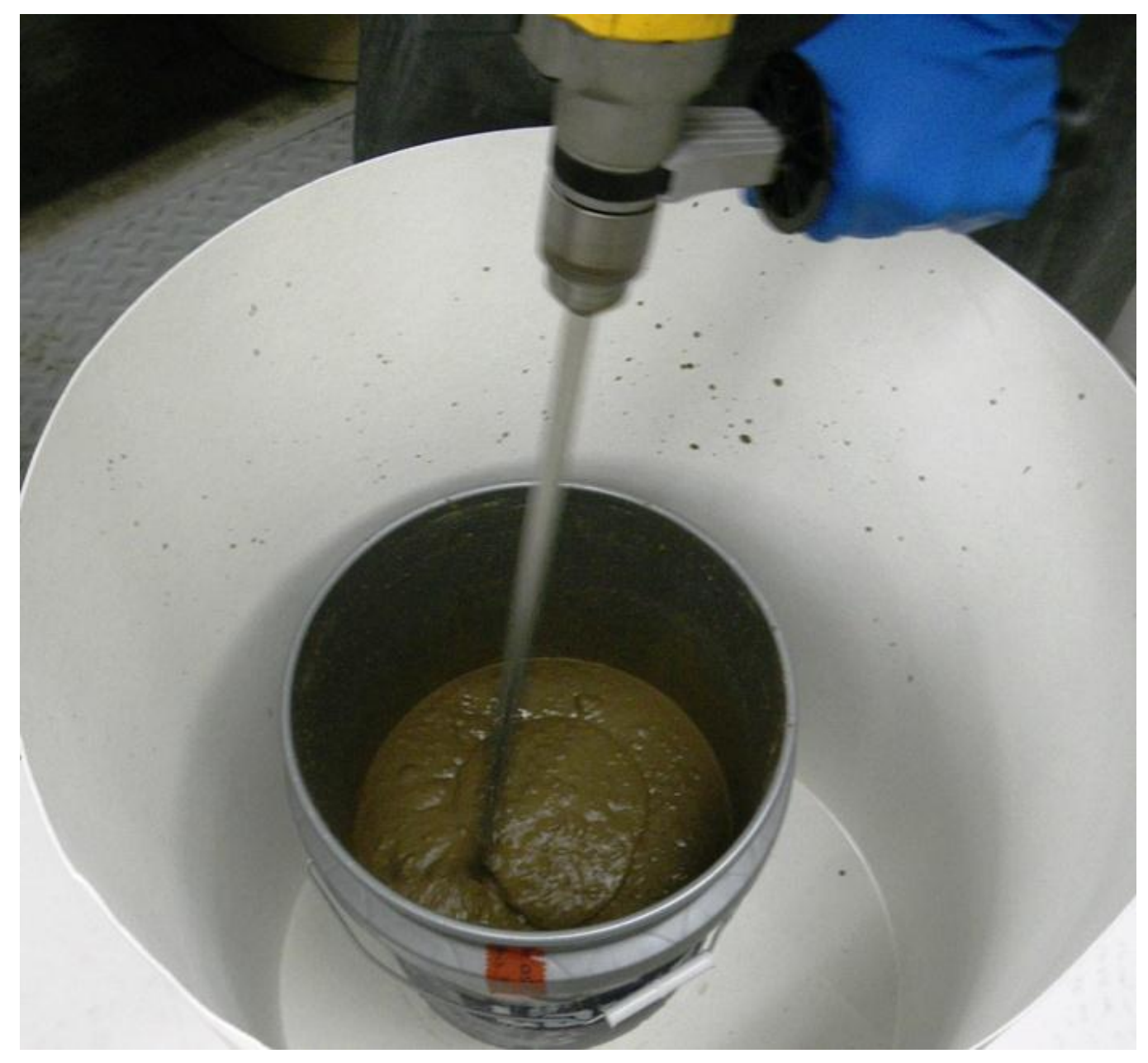

Figure 2. Sediment sample from the lower Emory River being mixed at ORNL with a customized stainless steel bit attached to a variable-speed drill. 


\section{Test Water}

Test and control water were obtained a day prior to the initiation of tests in pre-rinsed 4-L CUBITAINERS ${ }^{\circledR}$ (I-CHEM: Thermo Fisher Scientific) from the Emory River at ERM 8. Water was prefiltered as needed through a $0.45 \mu \mathrm{mm}$ or larger pore-size filter and subsequently sterile-filtered at 0.2 $\mu \mathrm{mm}$ prior to storage at $\leq 4^{\circ} \mathrm{C}$ in the dark for the duration of a test. Before use in initiating tests or in daily water changes of test chambers, aliquots of stored water were brought to $25 \pm 1^{\circ} \mathrm{C}$ in a water bath and/or temperature -controlled environmental chamber. Test water chemistry, including $\mathrm{pH}$, conductivity, alkalinity, hardness, and dissolved oxygen (DO), was analyzed prior to daily use, and DO and final $\mathrm{pH}$ were measured in daily discard water.

Dissolved oxygen $(\mathrm{mg} / \mathrm{L})$ was measured by EPA method 360.1 with a DO meter calibrated in accordance with the manufacturer's instructions. The $\mathrm{pH}$ was measured by EPA method 150.1 with an Orion $\mathrm{pH}$ meter calibrated with $\mathrm{pH} 4.0$ and $\mathrm{pH} 10.0$ buffers. Temperature was measured with a Fisher Scientific NIST-traceable thermometer according to ORNL SOPs. Conductance $(\mu \mathrm{S} / \mathrm{cm})$ was measured by EPA method 120.1 with a YSI meter; all values were corrected to $25^{\circ} \mathrm{C}$, and the meter was verified using certified reference standards. Alkalinity was measured by titrating $50 \mathrm{~mL}$ samples with $0.01 \mathrm{~N} \mathrm{HCl}$ to an endpoint $\mathrm{pH}$ of 4.5 (EPA method 310.1). Hardness was determined by titrating $50 \mathrm{~mL}$ samples with EDTA to a colorimetric endpoint using Eriochrome Black T (EPA method 130.2). Ammonia was monitored colormetrically with a freshwater test kit (Aquarium Pharmaceuticals, Inc).

\section{Test Organisms}

Embryos for tests were obtained from in-house fathead minnow cultures maintained by the Environmental Toxicology Laboratory within the Aquatic Ecology Laboratory at ORNL. On the morning of test initiation, fertilized eggs were collected from spawning tiles placed in stock aquaria on the prior afternoon, ensuring that embryos were $\leq 24$-hrs old at the time of collection. Eggs from at least five different aquaria were pooled and allowed to water-harden in aquarium water for approximately 1-hr after collection, then viable embryos $<6$-hr old as indicated by developmental stage were transferred to dishes containing filtered Emory River test water prior to randomization and final allocation to test dishes.

\section{Test Procedures}

Test procedures were adapted from an EPA fathead minnow 7-d embryo-larval survival and teratogenicity test method for effluents and receiving waters (method 1001.0 in EPA 2002). Tests were conducted July 2-9, 2010 (samples A, C, and D) and July 6-13, 2010 (sample B).

The day prior to the initiation of a test, approximately $35 \mathrm{~mL}$ of a sediment sample was layered on the bottom of each of four replicate $185-\mathrm{mL}$ polystyrene chambers and overlaid with $100 \mathrm{~mL}$ of test water (control dishes were provided $135 \mathrm{~mL}$ of test water only). Dishes were loosely covered with paraffin, randomly distributed in trays within environmental chambers maintained at $25 \pm 1{ }^{\circ} \mathrm{C}$, and allowed to settle overnight. As necessary, sediment levels were adjusted the following morning after initial settling to provide a final 1:3 sediment-to-water ratio by volume. Test chambers were then allowed to re-settle for at another $2-3 \mathrm{hrs}$, following which approximately $60 \%$ of test water was removed and carefully replaced with fresh water prior to use in a test.

Following randomization of the fertilized eggs, 15 embryos were transferred to each test chamber and carefully deposited directly to the surface of the settled sediment layers. In preliminary tests, nytex screens of varying grid size were cut and fitted to the surface of the sediment and eggs were deposited on these screens. However, the nytex screens tended to shift in the dishes due to inherent buoyancy and lack of rigidity, frequently causing the embryos to either be displaced under the screens or to roll into deposits 
of fine-grained sediment that formed in sagging areas of the screen. Furthermore, once the embryos hatched and became free-swimming, larvae tended to swim under the screens and occasionally became trapped in fine-grained sediments by the overlying screen. Placing the embryos directly on sediment provided both a more stable platform for pre-hatch development to proceed and a worst-case scenario for contact exposures to ash in the sediments during embryonic and early larval development.

For each test, embryos and larvae were incubated for 7-days through the absorption of the larval yolk sac without feeding in environmental chambers maintained at $25 \pm 1{ }^{\circ} \mathrm{C}$ with a $16 \mathrm{~L}: 8 \mathrm{D}$ photoperiod. Embryos were scored daily for survival, hatching success, and developmental abnormalities, and dead embryos or larvae were removed and discarded. Approximately $60 \%$ of the incubation test water was replaced daily in each test chamber with special care taken to minimize disturbance of the bottom sediment layer. In this respect, current practices differed from standard fathead minnow embryo-larval tests of effluents and receiving waters in which a greater percentage (90\% or more) of the test solution may be replaced daily.

At test termination, approximately $60 \%$ of the test solution was removed from each test chamber without disturbing the sediment or remaining embryos and larvae, following which an overdose of a fish anesthetic, tricane methanesulfonate (MS-222), was added to each chamber to immobilize and euthanize the test organisms. Embryos and/or larvae were removed from the test chambers with a transfer pipette and placed in clear polystyrene dishes for final scoring of survival and developmental abnormalities, followed by archival storage of remaining test organisms in formalin.

\section{Statistical Analyses}

Endpoints of the fathead minnow embryo-larval toxicity test were based on mortality, incidences of developmental abnormalities, and total number of dead and deformed embryos and/or larvae (EPA 2002). For the purposes of data analysis and presentation, any developmental abnormality scored at the time of test termination was considered lethal and those embryos and larvae were added to the final totals for mortality. An $\mathrm{EC}_{25}$ (concentration at which a $25 \%$ reduction in survival is expected) estimate was attempted for the concentration series 0\% (full-strength reference sediment) - 100\% (full-strength lower Emory River samples A - D) by Probit Analysis. With equal number of replicates, a NOEC (NoObserved-Effect-Concentration) was calculated from the arc sine-transformed data with Dunnett's procedure, a parametric statistical test, or a Steel's Rank Test, a non-parametric test, based on the results of a prior Shapiro-Wilk's Test for normality and a Bartlett's Test for homogeneity of variance. Survival in controls (Emory River test water only) was compared with survival in full-strength reference and ashcontaining sediments by 1 -way ANOVA and a Holm-Sidak pair-wise comparison procedure at $\mathrm{p}=0.05$. 

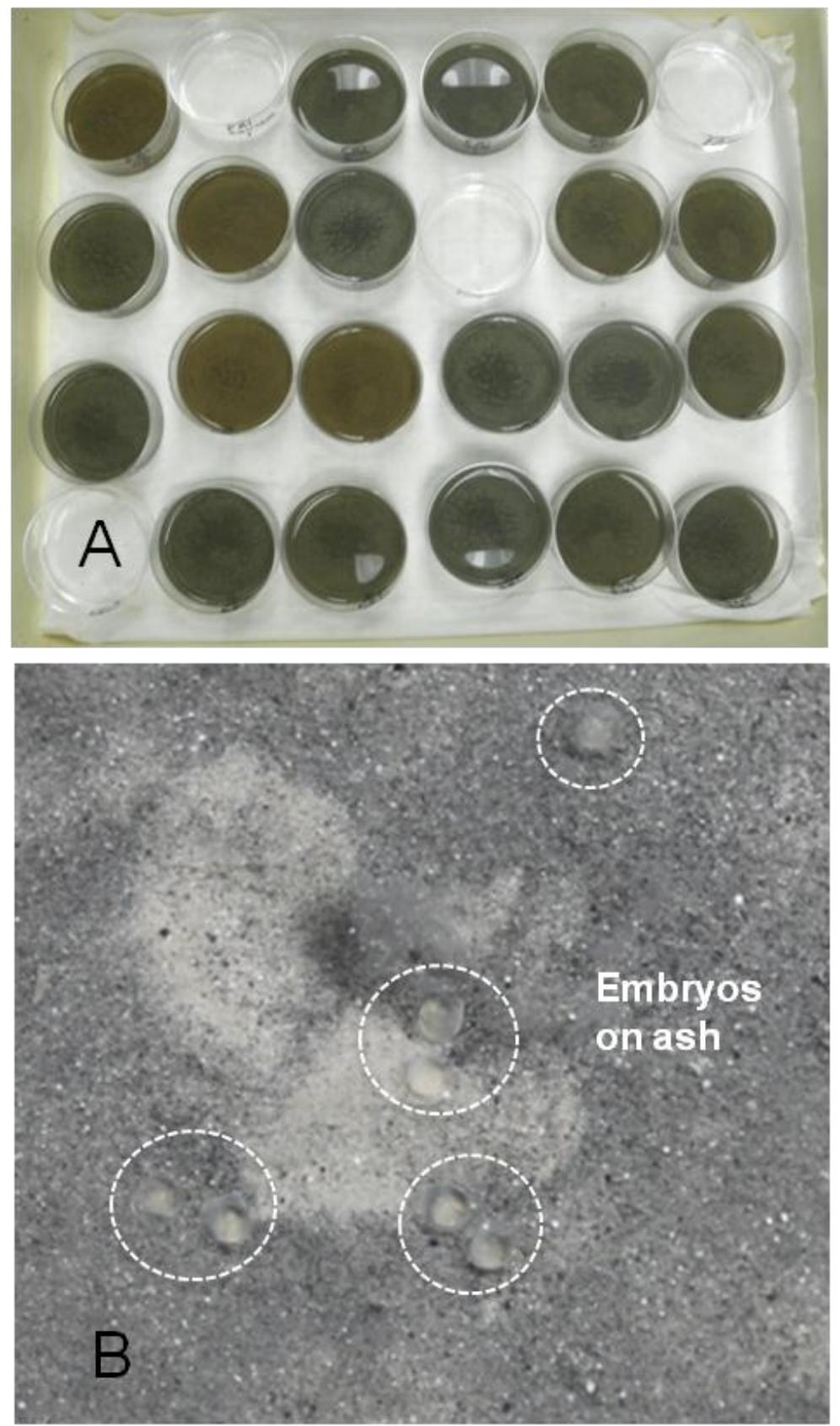

Figure 3. Fathead minnow embryo-larval test design of Emory River sediment samples: A) random distribution of test containers with sediment and/or control water; B) embryos on sediment in test chamber. 


\section{RESULTS}

Summary results for fathead minnow embryo-larval tests conducted on Emory River sediment samples are shown in Tables 4 - 7. Tests were performed on a concentration series of lower Emory River sediment samples containing fly ash from the Kingston spill (samples A - D) diluted with reference sediment collected from the Emory River upstream of the spill's influence. Mean survival in controls, consisting of filtered Emory River water without added sediment, was $80 \%$ or greater for each of the four tests (Figure 4).

Survival was relatively poor in a few sediment-containing test chambers (for instance, in the $75 \%$ concentration of sample B, replicate 3). Such results were exacerbated by the difficulty of observing sediment-coated embryos against a sediment background early during the time-course of a test, thus occasionally delaying the timely removal of dead embryos which could have impacted other embryos in the same test chamber. However, in none of the tests did total mortality, defined as the sum of dead and deformed embryos and/or larvae at test termination, differ significantly within a sediment dilution series (Tables $4-7$ ). Therefore, the NOEC was $100 \%$ for each of the tested sediment samples. The $\mathrm{EC}_{25}$ for survival could not be statistically calculated since total mortality did not differ significantly among groups; therefore, the $\mathrm{EC}_{25}$ was > $100 \%$ for each sample.

Hatching success was also relatively unaffected by exposure to sediment containing fly ash from the Kingston spill (Tables $4-7$ ). Variation in hatching success among replicates and between treatment groups (concentrations) was similar to variation between replicates and treatment groups in embryo mortality.

Incidences of developmental abnormalities were relatively low across all the tests, and the few deformities that did occur were typically lethal prior to the 7-d termination of the tests. Deformities ranged from sometimes transient edema and mild spinal curvatures to severely stunted embryos with numerous and varied deformities that typically resulted in death prior to test termination. The overall percentage of deformed embryos or larvae at test termination across the four tests was $<2 \%$ of the total embryos used in the tests (28 of 1440).

Embryo-larval survival in controls without sediment is compared in Figure 4 with survival in both 100\% lower Emory River sediment samples (samples A - D) and the reference sediment. Although embryo-larval survival tended in general to be somewhat less in sediment exposures than in control water exposures, only in the $100 \%$ reference sediment group of the sample D test was there a statistically significant reduction in survival as compared with control embryos.

Water chemistries conducted during these tests are summarized in Tables $8-9$. Control water chemistry was similar between tests. The $\mathrm{pH}, \mathrm{DO}$, and ammonia analyses of discard water indicated water quality remained acceptable between water changes despite replacing less water than typical for similar effluent or receiving water tests due to a need to minimize disturbance of sediment layers in the test chambers during changes. 
Table 4. Summary Data from Fathead Minnow Embryo-Larval Toxicity Test of Emory River Sediment Sample A. (sd = standard deviation).

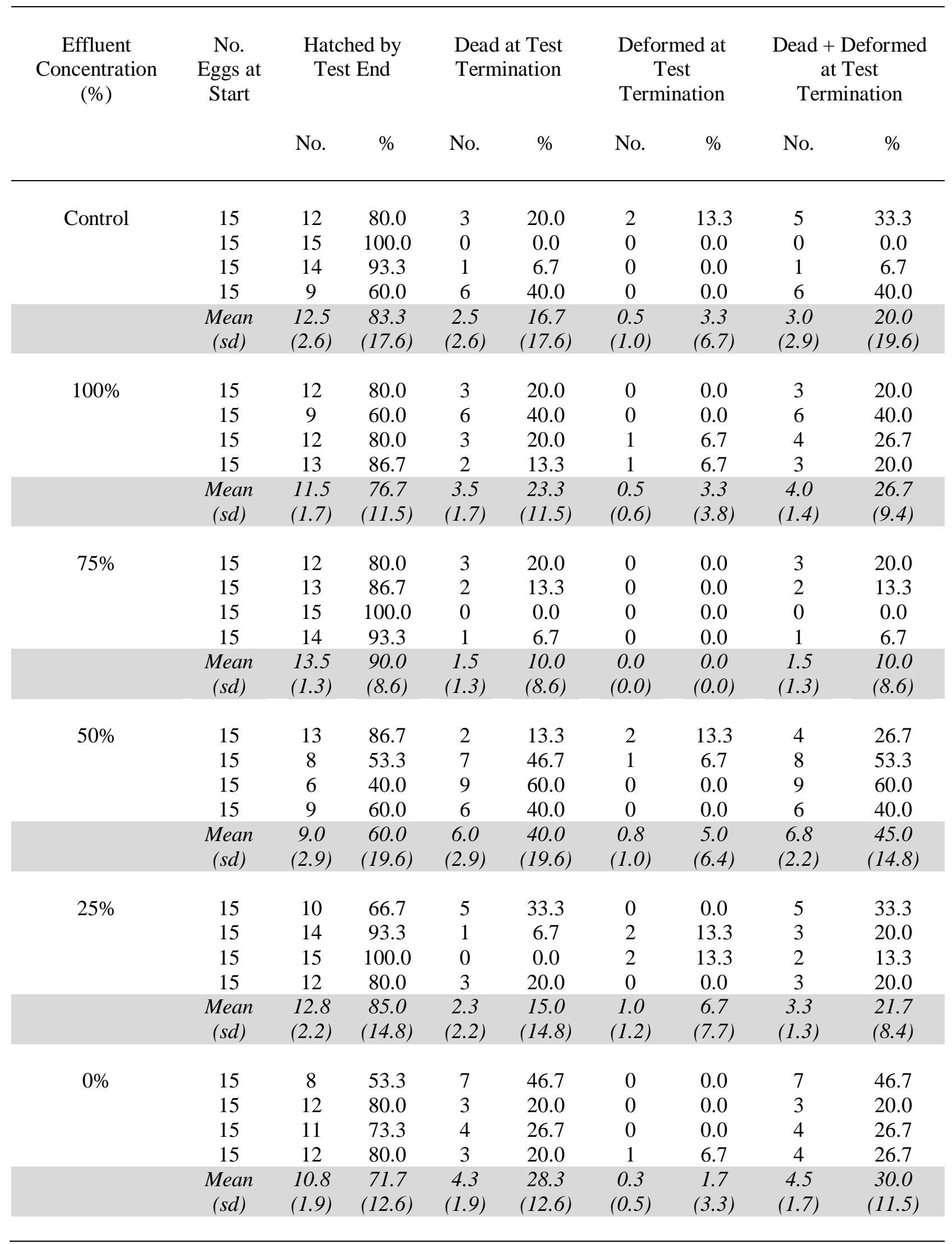


Table 5. Summary Data from Fathead Minnow Embryo-Larval Toxicity Test of Emory River Sediment Sample B. (sd = standard deviation).

\begin{tabular}{|c|c|c|c|c|c|c|c|c|c|}
\hline \multirow{2}{*}{$\begin{array}{c}\text { Effluent } \\
\text { Concentration } \\
(\%)\end{array}$} & \multirow{2}{*}{$\begin{array}{l}\text { No. } \\
\text { Eggs at } \\
\text { Start }\end{array}$} & \multicolumn{2}{|c|}{$\begin{array}{l}\text { Hatched by } \\
\text { Test End }\end{array}$} & \multicolumn{2}{|c|}{$\begin{array}{l}\text { Dead at Test } \\
\text { Termination }\end{array}$} & \multicolumn{2}{|c|}{$\begin{array}{c}\text { Deformed at } \\
\text { Test Termination }\end{array}$} & \multicolumn{2}{|c|}{$\begin{array}{c}\text { Dead + Deformed } \\
\text { at Test } \\
\text { Termination }\end{array}$} \\
\hline & & No. & $\%$ & No. & $\%$ & No. & $\%$ & No. & $\%$ \\
\hline \multirow[t]{5}{*}{ Control } & 15 & 11 & 73.3 & 4 & 26.7 & 0 & 0.0 & 4 & 26.7 \\
\hline & 15 & 10 & 66.7 & 5 & 33.3 & 0 & 0.0 & 5 & 33.3 \\
\hline & 15 & 13 & 86.7 & 2 & 13.3 & 0 & 0.0 & 2 & 13.3 \\
\hline & 15 & 14 & 93.3 & 1 & 6.7 & 0 & 0.0 & 1 & 6.7 \\
\hline & $\begin{array}{c}\text { Mean } \\
(s d)\end{array}$ & $\begin{array}{l}12.0 \\
(1.8)\end{array}$ & $\begin{array}{c}80.0 \\
(12.2)\end{array}$ & $\begin{array}{c}3.0 \\
(1.8)\end{array}$ & $\begin{array}{c}20.0 \\
(12.2)\end{array}$ & $\begin{array}{c}0.0 \\
(0.0)\end{array}$ & $\begin{array}{c}0.0 \\
(0.0)\end{array}$ & $\begin{array}{c}3.0 \\
(1.8)\end{array}$ & $\begin{array}{c}20.0 \\
(12.2)\end{array}$ \\
\hline \multirow[t]{5}{*}{$100 \%$} & 15 & 13 & 86.7 & 2 & 13.3 & 0 & 0.0 & 2 & 13.3 \\
\hline & 15 & 13 & 86.7 & 2 & 13.3 & 0 & 0.0 & 2 & 13.3 \\
\hline & 15 & 13 & 86.7 & 2 & 13.3 & 1 & 6.7 & 3 & 20.0 \\
\hline & 15 & 12 & 80.0 & 3 & 20.0 & 0 & 0.0 & 3 & 20.0 \\
\hline & $\begin{array}{c}\text { Mean } \\
(s d)\end{array}$ & $\begin{array}{l}12.8 \\
(0.5)\end{array}$ & $\begin{array}{l}85.0 \\
(3.3)\end{array}$ & $\begin{array}{c}2.3 \\
(0.5)\end{array}$ & $\begin{array}{l}15.0 \\
(3.3)\end{array}$ & $\begin{array}{c}0.3 \\
(0.5)\end{array}$ & $\begin{array}{c}1.7 \\
(3.3)\end{array}$ & $\begin{array}{c}2.5 \\
(0.6)\end{array}$ & $\begin{array}{l}16.7 \\
(38)\end{array}$ \\
\hline \multirow[t]{5}{*}{$75 \%$} & 15 & 13 & 86.7 & 2 & 13.3 & 0 & 0.0 & 2 & 13.3 \\
\hline & 15 & 10 & 66.7 & 5 & 33.3 & 0 & 0.0 & 5 & 33.3 \\
\hline & 15 & 2 & 13.3 & 13 & 86.7 & 0 & 0.0 & 13 & 86.7 \\
\hline & 15 & 8 & 53.3 & 7 & 46.7 & 3 & 20.0 & 10 & 66.7 \\
\hline & $\begin{array}{l}\text { Mean } \\
(s d)\end{array}$ & $\begin{array}{l}8.3 \\
(4.6)\end{array}$ & $\begin{array}{c}55.0 \\
(31.0)\end{array}$ & $\begin{array}{c}6.8 \\
(4.6)\end{array}$ & $\begin{array}{c}45.0 \\
(31.0)\end{array}$ & $\begin{array}{c}0.8 \\
(1.5)\end{array}$ & $\begin{array}{c}5.0 \\
(10.0)\end{array}$ & $\begin{array}{l}7.5 \\
(4.9)\end{array}$ & $\begin{array}{c}50.0 \\
(32.9)\end{array}$ \\
\hline \multirow[t]{5}{*}{$50 \%$} & 15 & 12 & 80.0 & 3 & 20.0 & 0 & 0.0 & 3 & 20.0 \\
\hline & 15 & 8 & 53.3 & 7 & 46.7 & 0 & 0.0 & 7 & 46.7 \\
\hline & 15 & 10 & 66.7 & 5 & 33.3 & 0 & 0.0 & 5 & 33.3 \\
\hline & 15 & 7 & 46.7 & 8 & 53.3 & 0 & 0.0 & 8 & 53.3 \\
\hline & $\begin{array}{l}\text { Mean } \\
(s d)\end{array}$ & $\begin{array}{c}9.3 \\
(2.2)\end{array}$ & $\begin{array}{c}61.7 \\
(14.8)\end{array}$ & $\begin{array}{l}5.8 \\
(2.2)\end{array}$ & $\begin{array}{c}38.3 \\
(14.8)\end{array}$ & $\begin{array}{c}0.0 \\
(0.0)\end{array}$ & $\begin{array}{c}0.0 \\
(0.0)\end{array}$ & $\begin{array}{c}5.8 \\
(2.2)\end{array}$ & $\begin{array}{c}38.3 \\
(14.8)\end{array}$ \\
\hline \multirow[t]{5}{*}{$25 \%$} & 15 & 7 & 46.7 & 8 & 53.3 & 0 & 0.0 & 8 & 53.3 \\
\hline & 15 & 12 & 80.0 & 3 & 20.0 & 0 & 0.0 & 3 & 20.0 \\
\hline & 15 & 12 & 80.0 & 3 & 20.0 & 0 & 0.0 & 3 & 20.0 \\
\hline & 15 & 11 & 73.3 & 4 & 26.7 & 0 & 0.0 & 4 & 26.7 \\
\hline & $\begin{array}{c}\text { Mean } \\
(s d)\end{array}$ & $\begin{array}{l}10.5 \\
(2.4)\end{array}$ & $\begin{array}{c}70.0 \\
(15.9)\end{array}$ & $\begin{array}{c}4.5 \\
(2.4)\end{array}$ & $\begin{array}{c}30.0 \\
(15.9)\end{array}$ & $\begin{array}{c}0.0 \\
(0.0)\end{array}$ & $\begin{array}{c}0.0 \\
(0.0)\end{array}$ & $\begin{array}{c}4.5 \\
(2.4)\end{array}$ & $\begin{array}{c}30.0 \\
(15.9)\end{array}$ \\
\hline \multirow[t]{5}{*}{$0 \%$} & 15 & 10 & 66.7 & 5 & 33.3 & 0 & 0.0 & 5 & 33.3 \\
\hline & 15 & 14 & 93.3 & 1 & 6.7 & 0 & 0.0 & 1 & 6.7 \\
\hline & 15 & 9 & 60.0 & 6 & 40.0 & 0 & 0.0 & 6 & 40.0 \\
\hline & 15 & 6 & 40.0 & 9 & 60.0 & 0 & 0.0 & 9 & 60.0 \\
\hline & $\begin{array}{c}\text { Mean } \\
(s d)\end{array}$ & $\begin{array}{c}9.8 \\
(3.3)\end{array}$ & $\begin{array}{c}65.0 \\
(22.0)\end{array}$ & $\begin{array}{c}5.3 \\
(3.3)\end{array}$ & $\begin{array}{c}35.0 \\
(22.0)\end{array}$ & $\begin{array}{c}0.0 \\
(0.0)\end{array}$ & $\begin{array}{c}0.0 \\
(0.0)\end{array}$ & $\begin{array}{c}5.3 \\
(3.3)\end{array}$ & $\begin{array}{c}35.0 \\
(22.0)\end{array}$ \\
\hline
\end{tabular}


Table 6. Summary Data from Fathead Minnow Embryo-Larval Toxicity Test of Emory River Sediment Sample C. ( $\mathrm{sd}=$ standard deviation).

\begin{tabular}{|c|c|c|c|c|c|c|c|c|c|}
\hline \multirow{2}{*}{$\begin{array}{c}\text { Effluent } \\
\text { Concentration } \\
(\%)\end{array}$} & \multirow{2}{*}{$\begin{array}{l}\text { No. } \\
\text { Eggs at } \\
\text { Start }\end{array}$} & \multicolumn{2}{|c|}{$\begin{array}{l}\text { Hatched by } \\
\text { Test End }\end{array}$} & \multicolumn{2}{|c|}{$\begin{array}{l}\text { Dead at Test } \\
\text { Termination }\end{array}$} & \multicolumn{2}{|c|}{$\begin{array}{l}\text { Deformed at } \\
\text { Test } \\
\text { Termination }\end{array}$} & \multicolumn{2}{|c|}{$\begin{array}{c}\text { Dead + Deformed } \\
\text { at Test } \\
\text { Termination }\end{array}$} \\
\hline & & No. & $\%$ & No. & $\%$ & No. & $\%$ & No. & $\%$ \\
\hline \multirow[t]{5}{*}{ Control } & 15 & 15 & 100.0 & 0 & 0.0 & 0 & 0.0 & 0 & 0.0 \\
\hline & 15 & 13 & 86.7 & 2 & 13.3 & 0 & 0.0 & 2 & 13.3 \\
\hline & 15 & 14 & 93.3 & 1 & 6.7 & 0 & 0.0 & 1 & 6.7 \\
\hline & 15 & 15 & 100.0 & 0 & 0.0 & 0 & 0.0 & 0 & 0.0 \\
\hline & $\begin{array}{c}\text { Mean } \\
(s d)\end{array}$ & $\begin{array}{l}14.3 \\
(1.0)\end{array}$ & $\begin{array}{l}95.0 \\
(6.4)\end{array}$ & $\begin{array}{c}0.8 \\
(1.0)\end{array}$ & $\begin{array}{c}5.0 \\
(6.4)\end{array}$ & $\begin{array}{c}0 \\
(0.0)\end{array}$ & $\begin{array}{c}0 \\
(0.0)\end{array}$ & $\begin{array}{c}0.8 \\
(1.0)\end{array}$ & $\begin{array}{c}5.0 \\
(6.4)\end{array}$ \\
\hline \multirow[t]{5}{*}{$100 \%$} & 15 & 14 & 93.3 & 1 & 6.7 & 0 & 0.0 & 1 & 6.7 \\
\hline & 15 & 9 & 60.0 & 6 & 40.0 & 0 & 0.0 & 6 & 40.0 \\
\hline & 15 & 14 & 93.3 & 1 & 6.7 & 0 & 0.0 & 1 & 6.7 \\
\hline & 15 & 12 & 80.0 & 3 & 20.0 & 0 & 0.0 & 3 & 20.0 \\
\hline & $\begin{array}{l}\text { Mean } \\
(s d)\end{array}$ & $\begin{array}{l}12.3 \\
(2.4)\end{array}$ & $\begin{array}{c}81.7 \\
(15.8)\end{array}$ & $\begin{array}{l}2.8 \\
(2.4)\end{array}$ & $\begin{array}{c}18.3 \\
(15.8)\end{array}$ & $\begin{array}{c}0 \\
(0.0)\end{array}$ & $\begin{array}{c}0 \\
(0.0)\end{array}$ & $\begin{array}{l}2.8 \\
(2.4)\end{array}$ & $\begin{array}{c}18.3 \\
(15.8)\end{array}$ \\
\hline \multirow[t]{5}{*}{$75 \%$} & 15 & 10 & 66.7 & 5 & 33.3 & 0 & 0.0 & 5 & 33.3 \\
\hline & 15 & 10 & 66.7 & 5 & 33.3 & 0 & 0.0 & 5 & 33.3 \\
\hline & 15 & 14 & 93.3 & 1 & 6.7 & 0 & 0.0 & 1 & 6.7 \\
\hline & 15 & 11 & 73.3 & 4 & 26.7 & 0 & 0.0 & 4 & 26.7 \\
\hline & $\begin{array}{c}\text { Mean } \\
(s d)\end{array}$ & $\begin{array}{l}11.3 \\
(1.9)\end{array}$ & $\begin{array}{c}75.0 \\
(12.6)\end{array}$ & $\begin{array}{l}3.8 \\
(1.9)\end{array}$ & $\begin{array}{c}25.0 \\
(12.6)\end{array}$ & $\begin{array}{c}0 \\
(0.0)\end{array}$ & $\begin{array}{c}0 \\
(0.0)\end{array}$ & $\begin{array}{c}3.8 \\
(1.9)\end{array}$ & $\begin{array}{c}25.0 \\
(12.6)\end{array}$ \\
\hline \multirow[t]{5}{*}{$50 \%$} & 15 & 14 & 93.3 & 1 & 6.7 & 0 & 0.0 & 1 & 6.7 \\
\hline & 15 & 14 & 93.3 & 1 & 6.7 & 0 & 0.0 & 1 & 6.7 \\
\hline & 15 & 15 & 100.0 & 0 & 0.0 & 0 & 0.0 & 0 & 0.0 \\
\hline & 15 & 14 & 93.3 & 1 & 6.7 & 0 & 0.0 & 1 & 6.7 \\
\hline & $\begin{array}{l}\text { Mean } \\
(s d)\end{array}$ & $\begin{array}{l}14.3 \\
(0.5)\end{array}$ & $\begin{array}{l}95.0 \\
(3.3)\end{array}$ & $\begin{array}{c}0.8 \\
(0.5)\end{array}$ & $\begin{array}{c}5.0 \\
(3.3)\end{array}$ & $\begin{array}{c}0 \\
(0.0)\end{array}$ & $\begin{array}{c}0 \\
(0.0)\end{array}$ & $\begin{array}{c}0.8 \\
(0.5)\end{array}$ & $\begin{array}{c}5.0 \\
(3.3)\end{array}$ \\
\hline \multirow[t]{5}{*}{$25 \%$} & 15 & 12 & 80.0 & 3 & 20.0 & 0 & 0.0 & 3 & 20.0 \\
\hline & 15 & 11 & 73.3 & 4 & 26.7 & 0 & 0.0 & 4 & 26.7 \\
\hline & 15 & 14 & 93.3 & 1 & 6.7 & 0 & 0.0 & 1 & 6.7 \\
\hline & 15 & 12 & 80.0 & 3 & 20.0 & 0 & 0.0 & 3 & 20.0 \\
\hline & $\begin{array}{l}\text { Mean } \\
(s d)\end{array}$ & $\begin{array}{l}12.3 \\
(1.3)\end{array}$ & $\begin{array}{l}81.7 \\
(8.4)\end{array}$ & $\begin{array}{l}2.8 \\
(1.3)\end{array}$ & $\begin{array}{l}18.3 \\
(8.4)\end{array}$ & $\begin{array}{c}0 \\
(0.0)\end{array}$ & $\begin{array}{c}0 \\
(0.0)\end{array}$ & $\begin{array}{c}2.8 \\
(1.3)\end{array}$ & $\begin{array}{l}18.3 \\
(8.4)\end{array}$ \\
\hline \multirow[t]{5}{*}{$0 \%$} & 15 & 12 & 80.0 & 3 & 20.0 & 0 & 0.0 & 3 & 20.0 \\
\hline & 15 & 12 & 80.0 & 3 & 20.0 & 0 & 0.0 & 3 & 20.0 \\
\hline & 15 & 13 & 86.7 & 2 & 13.3 & 0 & 0.0 & 2 & 13.3 \\
\hline & 15 & 15 & 100.0 & 0 & 0.0 & 0 & 0.0 & 0 & 0.0 \\
\hline & $\begin{array}{c}\text { Mean } \\
(s d)\end{array}$ & $\begin{array}{l}13.0 \\
(1.4)\end{array}$ & $\begin{array}{l}86.7 \\
(9.4)\end{array}$ & $\begin{array}{c}2.0 \\
(1.4)\end{array}$ & $\begin{array}{l}13.3 \\
(9.4)\end{array}$ & $\begin{array}{c}0 \\
(0.0)\end{array}$ & $\begin{array}{c}0 \\
(0.0)\end{array}$ & $\begin{array}{c}2.0 \\
(1.4)\end{array}$ & $\begin{array}{l}13.3 \\
(9.4)\end{array}$ \\
\hline
\end{tabular}


Table 7. Summary Data from Fathead Minnow Embryo-Larval Toxicity Test of Emory River Sediment Sample D. (sd = standard deviation).

\begin{tabular}{|c|c|c|c|c|c|c|c|c|c|}
\hline \multirow{2}{*}{$\begin{array}{c}\text { Effluent } \\
\text { Concentration } \\
(\%)\end{array}$} & \multirow{2}{*}{$\begin{array}{l}\text { No. } \\
\text { Eggs at } \\
\text { Start }\end{array}$} & \multicolumn{2}{|c|}{$\begin{array}{l}\text { Hatched by } \\
\text { Test End }\end{array}$} & \multicolumn{2}{|c|}{$\begin{array}{l}\text { Dead at Test } \\
\text { Termination }\end{array}$} & \multicolumn{2}{|c|}{$\begin{array}{l}\text { Deformed at } \\
\text { Test } \\
\text { Termination }\end{array}$} & \multicolumn{2}{|c|}{$\begin{array}{c}\text { Dead }+ \text { Deformed } \\
\text { at Test } \\
\text { Termination }\end{array}$} \\
\hline & & No. & $\%$ & No. & $\%$ & No. & $\%$ & No. & $\%$ \\
\hline \multirow[t]{5}{*}{ Control } & 15 & 14 & 93.3 & 1 & 6.7 & 0 & 0.0 & 1 & 6.7 \\
\hline & 15 & 14 & 93.3 & 1 & 6.7 & 0 & 0.0 & 1 & 6.7 \\
\hline & 15 & 15 & 100.0 & 0 & 0.0 & 0 & 0.0 & 0 & 0.0 \\
\hline & 15 & 15 & 100.0 & 0 & 0.0 & 1 & 6.7 & 1 & 6.7 \\
\hline & $\begin{array}{c}\text { Mean } \\
(s d)\end{array}$ & $\begin{array}{l}14.5 \\
(0.6)\end{array}$ & $\begin{array}{c}96.7 \\
(3.8)\end{array}$ & $\begin{array}{c}0.5 \\
(0.6)\end{array}$ & $\begin{array}{c}3.3 \\
(3.8)\end{array}$ & $\begin{array}{c}0.3 \\
(0.5)\end{array}$ & $\begin{array}{c}1.7 \\
(3.3)\end{array}$ & $\begin{array}{c}0.8 \\
(0.5)\end{array}$ & $\begin{array}{c}5.0 \\
(3.3)\end{array}$ \\
\hline \multirow[t]{5}{*}{$100 \%$} & 15 & 11 & 73.3 & 4 & 26.7 & 0 & 0.0 & 4 & 26.7 \\
\hline & 15 & 11 & 73.3 & 4 & 26.7 & 0 & 0.0 & 4 & 26.7 \\
\hline & 15 & 14 & 93.3 & 1 & 6.7 & 0 & 0.0 & 1 & 6.7 \\
\hline & 15 & 12 & 80.0 & 3 & 20.0 & 2 & 13.3 & 5 & 33.3 \\
\hline & $\begin{array}{c}\text { Mean } \\
(s d)\end{array}$ & $\begin{array}{l}12.0 \\
(1.4)\end{array}$ & $\begin{array}{l}80.0 \\
(9.4)\end{array}$ & $\begin{array}{c}3.0 \\
(1.4)\end{array}$ & $\begin{array}{l}20.0 \\
(9.4)\end{array}$ & $\begin{array}{c}0.5 \\
(1.0)\end{array}$ & $\begin{array}{c}3.3 \\
(6.7)\end{array}$ & $\begin{array}{c}3.5 \\
(1.7)\end{array}$ & $\begin{array}{c}23.3 \\
(11.5)\end{array}$ \\
\hline \multirow[t]{5}{*}{$75 \%$} & 15 & 13 & 86.7 & 2 & 13.3 & 0 & 0.0 & 2 & 13.3 \\
\hline & 15 & 10 & 66.7 & 5 & 33.3 & 0 & 0.0 & 5 & 33.3 \\
\hline & 15 & 13 & 86.7 & 2 & 13.3 & 1 & 6.7 & 3 & 20.0 \\
\hline & 15 & 12 & 80.0 & 3 & 20.0 & 0 & 0.0 & 3 & 20.0 \\
\hline & $\begin{array}{c}\text { Mean } \\
\text { (sd) }\end{array}$ & $\begin{array}{l}12.0 \\
(1.4)\end{array}$ & $\begin{array}{l}80.0 \\
(9.4)\end{array}$ & $\begin{array}{c}3.0 \\
(1.4)\end{array}$ & $\begin{array}{l}20.0 \\
(9.4)\end{array}$ & $\begin{array}{c}0.3 \\
(0.5)\end{array}$ & $\begin{array}{c}1.7 \\
(3.3)\end{array}$ & $\begin{array}{c}3.3 \\
(1.3)\end{array}$ & $\begin{array}{l}21.7 \\
(8.4)\end{array}$ \\
\hline \multirow[t]{5}{*}{$50 \%$} & 15 & 12 & 80.0 & 3 & 20.0 & 0 & 0.0 & 3 & 20.0 \\
\hline & 15 & 11 & 73.3 & 4 & 26.7 & 3 & 20.0 & 7 & 46.7 \\
\hline & 15 & 8 & 53.3 & 7 & 46.7 & 2 & 13.3 & 9 & 60.0 \\
\hline & 15 & 8 & 53.3 & 7 & 46.7 & 1 & 6.7 & 8 & 53.3 \\
\hline & $\begin{array}{c}\text { Mean } \\
(s d)\end{array}$ & $\begin{array}{l}9.8 \\
(2.1)\end{array}$ & $\begin{array}{c}65.0 \\
(13.7)\end{array}$ & $\begin{array}{l}5.3 \\
(2.1)\end{array}$ & $\begin{array}{c}35.0 \\
(13.7)\end{array}$ & $\begin{array}{c}1.5 \\
(1.3)\end{array}$ & $\begin{array}{l}10.0 \\
(8.6)\end{array}$ & $\begin{array}{c}6.8 \\
(2.6)\end{array}$ & $\begin{array}{c}45.0 \\
(17.5)\end{array}$ \\
\hline \multirow[t]{5}{*}{$25 \%$} & 15 & 15 & 100.0 & 0 & 0.0 & 0 & 0.0 & 0 & 0.0 \\
\hline & 15 & 6 & 40.0 & 9 & 60.0 & 0 & 0.0 & 9 & 60.0 \\
\hline & 15 & 10 & 66.7 & 5 & 33.3 & 1 & 6.7 & 6 & 40.0 \\
\hline & 15 & 6 & 40.0 & 9 & 60.0 & 2 & 13.3 & 11 & 73.3 \\
\hline & $\begin{array}{c}\text { Mean } \\
(s d)\end{array}$ & $\begin{array}{c}9.3 \\
(4.3)\end{array}$ & $\begin{array}{c}61.7 \\
(28.5)\end{array}$ & $\begin{array}{c}5.8 \\
(4.3)\end{array}$ & $\begin{array}{c}38.3 \\
(28.5)\end{array}$ & $\begin{array}{c}0.8 \\
(1.0)\end{array}$ & $\begin{array}{l}5.0 \\
(6.4)\end{array}$ & $\begin{array}{c}6.5 \\
(4.8)\end{array}$ & $\begin{array}{c}43.3 \\
(32.0)\end{array}$ \\
\hline \multirow[t]{5}{*}{$0 \%$} & 15 & 11 & 73.3 & 3 & 20.0 & 0 & 0.0 & 3 & 20.0 \\
\hline & 15 & 6 & 40.0 & 9 & 60.0 & 1 & 6.7 & 10 & 66.7 \\
\hline & 15 & 12 & 80.0 & 3 & 20.0 & 0 & 0.0 & 3 & 20.0 \\
\hline & 15 & 10 & 66.7 & 5 & 33.3 & 0 & 0.0 & 5 & 33.3 \\
\hline & $\begin{array}{c}\text { Mean } \\
(s d)\end{array}$ & $\begin{array}{c}9.8 \\
(2.6)\end{array}$ & $\begin{array}{c}65.0 \\
(17.5)\end{array}$ & $\begin{array}{c}5.0 \\
(2.8)\end{array}$ & $\begin{array}{c}33.3 \\
(18.9)\end{array}$ & $\begin{array}{c}0.3 \\
(0.5)\end{array}$ & $\begin{array}{c}1.7 \\
(3.3)\end{array}$ & $\begin{array}{c}5.3 \\
(3.3)\end{array}$ & $\begin{array}{c}35.0 \\
(22.0)\end{array}$ \\
\hline
\end{tabular}




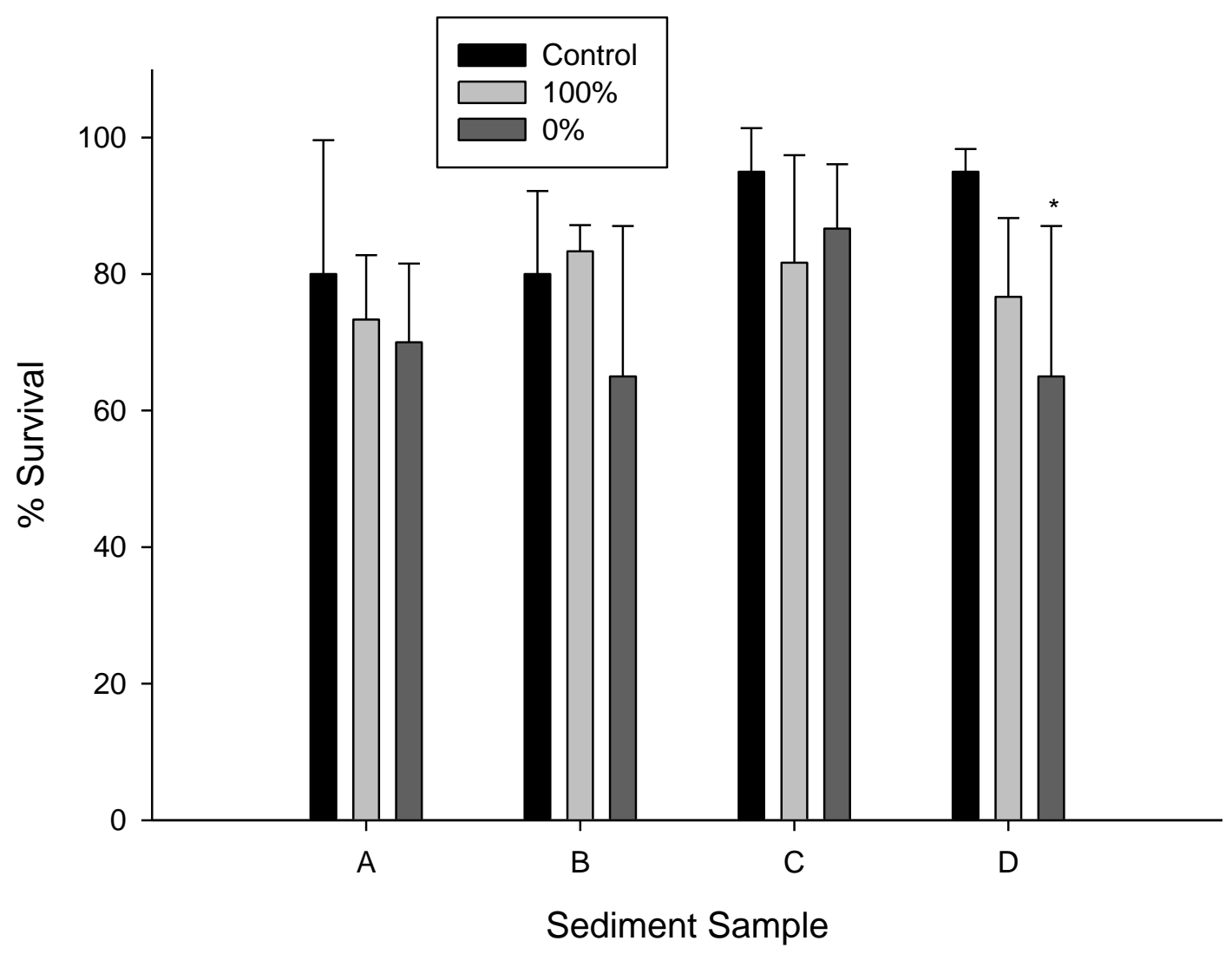

Figure 4. Comparison of fathead minnow embryo-larval survival in Emory River water from ERM 8 upstream of the fly ash spill (controls) withsurvival on full-strength sediment samples containing fly ash from the lower Emory River $(\mathbf{1 0 0 \%})$ and reference sediment without fly ash from the upper

Emory River (0\%). Expressed as means \pm standard deviations of four replicates; asterisk signifies a statistical decrease from the control $(\mathrm{p}=0.05)$. 
Table 8. Summary (mean $\pm \mathrm{sd}^{a}$ ) of control water ${ }^{b}$ chemistry analyses conducted during fathead minnow embryo-larval toxicity testing of Emory River sediment samples.

\begin{tabular}{|c|c|c|c|c|}
\hline Sample & $\begin{array}{c}\mathrm{pH} \\
\text { (standard units) }\end{array}$ & $\begin{array}{c}\text { Alkalinity } \\
\left(\mathrm{mg} / \mathrm{L} \text { as } \mathrm{CaCO}_{3}\right)\end{array}$ & $\begin{array}{c}\text { Hardness } \\
\left(\mathrm{mg} / \mathrm{L} \text { as } \mathrm{CaCO}_{3}\right)\end{array}$ & $\begin{array}{l}\text { Conductivity } \\
\qquad(\mu \mathrm{S} / \mathrm{cm})\end{array}$ \\
\hline $\begin{array}{l}\text { Control } 1 \\
\text { (Samples A, C, D) }\end{array}$ & $7.45(0.09)$ & $50.4(1.7)$ & $57.9(1.2)$ & $130.3(2.3)$ \\
\hline $\begin{array}{l}\text { Control } 2 \\
\text { (Sample B) }\end{array}$ & $7.51(0.05)$ & $49.7(2.2)$ & $57.7(2.3)$ & $131.7(3.2)$ \\
\hline
\end{tabular}

Table 9. Summary (mean $\pm \mathbf{s d}^{a}$ ) of water chemistry analyses conducted on "discard" water removed from test chambers during daily water changes of fathead minnow embryo-larval toxicity test chambers.

\begin{tabular}{lccc}
\hline \multicolumn{1}{c}{ Sample } & $\begin{array}{c}\text { Final pH } \\
(\text { standard units })\end{array}$ & $\begin{array}{c}\text { Final DO } \\
(\mathrm{mg} / \mathrm{L})\end{array}$ & $\begin{array}{c}\text { Ammonia } \\
(\mathrm{mg} / \mathrm{L})\end{array}$ \\
\hline Control 1 (Samples A, C, D) & $7.66(0.13)$ & $8.41(0.15)$ & $0.13(0.13)$ \\
Control 2 (Sample B) & $7.62(0.12)$ & $8.37(0.16)$ & $0.25(0.00)$ \\
A & $7.85(0.03)$ & $8.39(0.09)$ & $0.04(0.09)$ \\
B & $7.89(0.09)$ & $8.37(0.08)$ & 0 \\
C & $7.85(0.05)$ & $8.39(0.09)$ & $0.39(0.20)$ \\
D & $7.81(0.05)$ & $8.41(0.11)$ & $0.07(0.19)$ \\
Reference sediment & $7.25(0.17)$ & $8.39(0.12)$ & $0.07(0.12)$ \\
\hline${ }^{a}$ sd = standard deviation & & &
\end{tabular}


[THIS PAGE LEFT BLANK INTENTIONALLY] 


\section{CONCLUSIONS}

Direct contact exposures of fathead minnow eggs to sediments from the Emory River containing up to $78 \%$ ash from the Kingston fly ash spill had no significant effects on embryonic or early larval development in these relatively short-term laboratory tests, although chemical constituents with known toxic effects on fish early larval stages, particularly selenium, were significantly elevated in the tested samples (Table 3). Developmental endpoints, including embryo-larval survival, hatching success, and the incidences of developmental abnormalities, did not differ significantly across concentration series ranging from $0 \%$ to $100 \%$ of each fly-ash contaminated sediment sample. These results thus do not support a hypothesis that fly ash in areas of the Emory and Clinch Rivers affected by the fly ash spill presents a significant risk to developing fish eggs from direct (versus food-chain derived) chemical toxicity, either from contact with ash or exposure to constituents potentially leaching from the sediment into overlying river water. That many of the developing embryos in these tests were relatively coated with sediment from inadvertent disturbances during handling of test chambers and water changes provided further evidence of a lack of a significant direct toxic effect in these worst-case experimental exposures.

There are naturally caveats that should be considered in interpreting these laboratory test results. For instance, it could be argued that the fathead minnow is not a native fish species in the lower Emory and Clinch Rivers and thus may not be truly representative of the risks that fly ash exposure might pose to the eggs of sunfish, largemouth bass, and other fish present in the affected areas. However, the fathead minnow has been a standard model organism for toxicity testing in the US for many years precisely because test results with this species have been relatively well-correlated with the ecological risks of a variety of chemical contaminants, including heavy metals. Furthermore, the ease of raising these fish in the laboratory and obtaining eggs at desired ages for such embryo-larval testing may be unparalleled among fish native to the US - if not to these particular river systems.

Another, and potentially much more significant consideration in interpreting the present results, is the age of the embryos at the initiation of these tests. Embryos chosen for these studies were typically < 6-hr post-fertilization when placed in the sediment-containing test chambers, in contrast with the EPA method for fathead minnow embryo-larval tests which only specifies that embryos are at least $<36-\mathrm{hr}$ post-fertilization when used for effluent and receiving water testing. However, even our initiating these tests at such a comparatively early post-fertilization stage compared to guidelines still failed to encompass the critical water-hardening or "swelling" stage of embryonic development that occurs shortly after fertilization, a very early developmental stage in which fertilized eggs may be particularly susceptible to 
the absorption of chemical contaminants (Jezierska and others 2009). Achieving exposures that include the fertilization and subsequent water-hardening of the fertilized eggs would entail spawning adult fish directly over ash-bearing sediment which is not practical in such short-term toxicity tests. However, in another phase of our ongoing studies, we have conducted longer-term exposures of adult fathead minnows to fly ash from the Kingston spill site and will present results in a future report.

Although the present fathead minnow tests were never intended to address food chain-related questions concerning the potential risks of the Kingston fly ash spill to the reproduction and early development of fish populations affected by the fly ash spill, such questions should be factored into the interpretation and extrapolation of these test results to wild fish populations. In situ exposures to fish populations in the wild would undoubtedly include food chain exposures as well as the direct and waterborne exposures tested in our fathead minnow studies, and the cumulative impacts of such exposures have been shown to be additive in at least some cases (Woock and others 1987, Coyle and others 1993). Thus, the absence of observable effects in the current laboratory embryo-larval tests, although not supporting a hypothesis that direct contact and water-borne exposures to fly ash in the Emory and Clinch River systems present a significant risk to developing fish eggs, also does not conclusively prove that such risks might not exist in fish eggs previously affected by the maternal transfer of fly ash constituents prior to direct exposures. Several such potential complicating factors are currently being addressed through ongoing studies of fish reproduction and ovarian contaminant burdens in these river systems, as well as in an in vitro spawning study recently completed on redear sunfish that will be documented in a future report.

In conclusion, direct contact exposures of fathead minnow eggs to fly ash-contaminated sediments from the Emory River had no significant effects on embryonic or early larval development in 7-d embryo-larval laboratory tests.

\section{Summary results of fathead minnow embryo-larval tests:}

NOEC for sediment samples $A-D=100 \%$

$\mathrm{EC}_{25}$ for sediment samples $\mathrm{A}-\mathrm{D}=>\mathbf{1 0 0 \%}$ 


\section{REFERENCES}

Coyle, J. J., D. R. Buckler, C. G. Ingersoll, J. F. Fairchild, and T. W. May. 1993. Effect of dietary selenium on the reproductive success of bluegills (Lepomis macrochirus). Environmental Toxicology and Chemistry 12: 551-565.

Devlin, E. W. 2006. Acute toxicity, uptake and histopathology of aqueous methyl mercury to fathead minnow embryos. Environmental Toxicology and Chemistry 7: 27-34.

EPA. 2002. Short-Term Methods for Estimating the Chronic Toxicity of Effluent and Receiving Waters to Freshwater Organisms, EPA/821/R/02/013, $4^{\text {th }}$ Ed., October 2002.

Jezierska, B., K. Lugowska, and M. Witeska. 2009. The effects of heavy metals on embryonic development of fish (a review). Fish Physiology and Biochemistry 35: 625-640.

Lemly, A. D. 1999. Selenium impacts on fish: an insidious time bomb. Human and Ecological Risk Assessment 5(6): 1139-1151.

Muscatello, J. R., P. M. Bennett, K. T. Himbeault, A. M. Belknap, and D. M. Janz. 2006. Larval deformities associated with selenium accumulation in northern pike (Esox lucius) exposed to metal mining effluent. Environmental Science and Technology 40: 6505-6512.

Woock, S. E., W. R. Garrett, W. E. Partin, and W. T. Bryson. 1987. Decreased survival and teratogenesis during laboratory selenium exposures to bluegill, Lepomis macrochirus. Bulletin of Environmental Contamination and Toxicology 39: 998-1005. 